sonally so dear to me) are lying in their cots, and many a sick boy, come down to the war from Ohio, Illinois, Wisconsin, and the rest.

WALT WhitMan.

\title{
"I'LL TRACE THIS GARDEN": A NOTE ON A NON-WHITMAN AT- TRIBUTION
}

There is little basis for a Whitman attribution that appears in the "Uncollected Manuscript Fragments" section of Leaves of Grass, Comprehensive Reader's Edition, ed. Harold W. Blodgett and Sculley Bradley (New York: New York University Press, 1965). pp. 697-698. The holograph poem, in the Feinberg-Whitman Collection, Library of Congress Manuscript Division, reads:

\author{
[I'll Trace This Garden] \\ 1
}

I'll trace this garden oer \& oer

Meditate on each sweet flower

Thinking of each happy hour

$$
2
$$

Some say my love is gone to France

3

I'll sell my frock - I'll sell my where ${ }^{1}$

4

I wish I was on yonder hill

It's there I'd sit \& cry my fill

So every tear should turn a mill

5

I'll dye my dress - I'll dye it red

Over the world I'll beg my bread

My parents dear shall think me dead

This undated, untitled, and unsigned poem was written in black ink on the letterhead of the Attorney General's Office, Washington, D.C., where Whitman served from 1 July 1865 to 1873 , when he suffered a stroke and a year later left government service. The poem is written without revision in a clear, even hand, and is unlike anything Whitman ever wrote for Leaves of Grass, with its syrupy subject matter, child-like rhyme scheme, and absence of any terminal punctuation.

Fortunately, another poem survives that Whitman had written out during this period on the blank side of another Attorney General's Office letterhead, and this apparently clears up the mystery of how the "Garden" poem came to be in Whitman's hand. Whitman had written out Emerson's poem "Brahma" without title or author's name in black ink, in a clear, even hand. (Whether he wrote out both poems around the same time cannot be determined.) The "Brahma" holograph is in the same folder as the "Garden" poem. ${ }^{2}$ Whitman's errors in transcription clearly show that he was not copying out the four-stanza, sixteen-line "Brahma" from a printed source, but was recalling it from memory. He knew the poem well. Nevertheless, ampersands 
aside, there are two substantive departures from Emerson's text and a mended misspelling - "subtle" for "subtile" - in the first stanza, two interlined corrections in the second and fourth stanzas, a lower-case "b" for "Brahmin" in the third, and six errors in terminal punctuation.

Within this context, it would be reasonable to conclude that Whitman was simply passing the time by writing out from memory two poems that had appealed to him. His apparent admiration for poems of such diverse accomplishment as "Brahma" and "Garden" certainly shows for the latter a peculiar catholicity of taste. But that Whitman had actually composed the "Garden" piece during the important 1865-1873 period is something else again. These years saw the publication of DrumTaps (1865), Sequel to Drum-Taps (1865-6), containing "When Lilacs Last in the Dooryard Bloom'd," the 1867 (fourth) edition of Leaves of Grass, the annex Passage to India (1871), containing the title poem, and the 1871 (fifth) edition of Leaves.

The note on p. 697 acknowledges that ". . . this verse is most atypical of Whitman's poems of the period. One can only surmise that either the poet was recalling a ballad he had heard, or that he was trying his own hand." The evidence clearly supports the former conjecture. ${ }^{3}$

The City College, New York

ARTHUR Golden

\section{NOTES}

1 A probable lapse for "ware."

2 Container 27. A note in the folder attributes "Brahma" to Emerson, but the holograph itself is not listed in the index to the Feinberg Collection or on the folder.

3 I have been unsuccessful in locating the authorship of this poem, but those I've queried generally support its place among the sentimental magazine or newspaper verses of the period.

\section{EBEN J. - NOT ELIAS J. - LOOMIS IN WHITMAN'S CORRESPONDENCE AND DAYBOOKS}

Polly Longsworth's Austin and Mabel: The Amherst Affair \& Love Letters of Austin Dickinson and Mabel Loomis Todd (New York: Farrar, Straus, Giroux, 1984) is the last place one might expect to find anything about Walt Whitman. But on p.13, and also on p. 18, we read that Mabel Loomis Todd's father, Eben Jenks Loomis, took walks with Whitman when he was in Washington between 1867 and 1872. Loomis, his daughter learned, distorted the truth about himself-"Exaggeration, it was, rather than lying" - and he was never a "mathematician, scientist, astronomer, philosopher, or professor-all titles by which his family identified him" (p. 15). But for 50 years, beginning about 1851, he was little more than a clerk (later a Senior Assistant) in the Nautical Almanac Office in Washington. According to his daughter, he was born in 1828 and died in 1912.

In a letter dated 25 June 1882 to William D. O'Connor, Whitman writes that he sent a copy of Leaves of Grass "to Prof. Loomis" (The Correspondence, edited by Edwin 